\title{
MITOS DAN MEMORI \\ MENGACA PADA STATUS JANDA DANYANG SARWITI DAN PENGARUHNYA DI NGANJUK
}

\author{
Depy Tri Budi Siswanto 1 \\ Latif Kusairi² $^{2}$ \\ Peneliti Pusdeham Surabaya \\ depysiswanto@gmail.com
}

\begin{abstract}
Abstrak
Penelitian ini bertujuan mengetahui persepsi masyarakat Desa Banjardowo, Kec. Lengkong, Kab. Nganjuk, Jawa Timur terhadap status janda seumur hidup yang akan disandang oleh seorang wanita ketika wanita tersebut menjadi janda. Pengumpulan data diawali dengan studi pustaka dan dilanjutkan dengan wawancara, perekaman, observasi dan pencatatan. Hasil penelitinan ini menunjukan kepercayaan masyarakat yang tinggi terhadap Danyang Desa. "Danyang" adalah sebutan untuk seorang tokoh yang dipercaya sebagai pendiri perkampungan. "Danyang" Desa Banjardowo bernama Sarwiti. Kisah Sarwiti yang menjanda sampai akhir hidupnya menjadi pangkal kultur janda seumur hidup di Desa Banjardowo. Masyarakat Desa Banjardowo menganggap status janda seumur hidup ini adalah turunan dari sang "Danyang" dan akan terlaksana jika seorang wanita menjanda. Sarwiti dipercayai masih hidup hingga sekarang dan tinggal di tempat yang bernama Ngasgunting.
\end{abstract}

\section{Kata Kunci: Kampung Janda, Danyang, Masyarakat Banjardowo, Sarwiti}

\begin{abstract}
The purpose of this study to obtain the perception of people in Kampong Banjardowo, Lengkong District, Nganjuk Regency, East Java, towards the status of a long-life widow, that will attach to woman since she become a widow. The collection of the data has conducted by examine the literature review, interview, data observation, and data recording. The result of this study shows the strong belief of this community towards Danyang Desa. 'Danyang' is the one who is believed become the founder of the settlement. 'Danyang' of Kampong Banjardowo is called Sarwiti. The story of Sarwiti who is the widow till the end of her life becomes the beginning of 'long-life widow' culture in Kampong Banjardowo. People of Kampong Banjardowo consider that the status of 'long-life widow' is derived from 'Danyang' and it will accomplish since the woman become a widow. Sarwiti is believed still alive; she lives in somewhere that is named Ngasgunting
\end{abstract}

Keywords: Kampong of Widow, Danyang, People of Banjardowo, Sarwiti

1 Prodi Pendidikan Sejarah, Universitas Nusantara PGRI Kediri, Kota Kediri. Jl. KH Achmad Dahlan No.76, Kota Kediri e-mail: depysiswanto@gmail.com

2 Alumnus Pascasarjana IImu Sejarah UGM. 


\section{Pendahuluan}

Kepercayaan menurut Kamus

Besar Bahasa Indonesia adalah anggapan atau keyakinan bahwa sesuatu yang dipercayaai itu benar atau nyata. ${ }^{3}$ Kepercayaan diciptakan dari, untuk, dan oleh manusia itu sendiri. Kepercayaan tersebut adalah jawaban dari pertanyaan yang tidak dapat dijawab oleh mereka sendiri. Masyarakat Jawa umumnya mempercayai adanya suatu kekuatan yang dapat memengaruhi kehidupan mereka. Kepercayaan ini direresentasikan dalam berbagai bentuk. Masuknya agama-agama di Nusantara tidak membuat sebagian dari kepercayaan lama Jawa ini tergerus.

Kenyataan historis menunjukan bahwa jauh sebelum Islam tersebar di tanah Jawa; masyarakat Jawa telah terlebih dahulu "digarap" oleh kepercayaan atau agama Hindu-Buddha. Namun sejak dahulu inti dan pusat dari segala kepercayaan Jawa adalah magis-mistik. ${ }^{4}$ Ketika Islam masuk dan diterima masyarakat Jawa pada sekitar abad ke-15 Masehi, terjadilah "perubahan wajah" yang ditampilkan orang Jawa. Banyak pengamat menilai, Islam yang dianut orang Jawa adalah hasil asimilasi antara

3 Pusat Bahasa Departemen Pendidikan Nasional, Kamus Bahasa Indonesia, (Jakarta: Pusat Bahasa, 2008), hlm. 1158.

${ }_{4}$ S. de Jong, Salah satu sikap hipup orang Jawa, (Yogyakarta: Kanisus, 1976), hlm. 12. Dalam Mulyana, "Spiritualisme Jawa: Meraba Demensi dan Pergulatan Religiusitas Orang Jawa", Jurnal Kebudayaan Jawa, Vol. 1 No. 2 Agustus 2006, hlm. 5. kepercayaan Jawa asli, Hindu-Buddha, dan Islam. ${ }^{5}$

Salah satu kebudayaan yang dihasilkan dari sana adalah upacara bersih desa (Nyadranan). Upacara bersih desa biasanya dilangsungkan satu tempat dekat makam pendiri desa (Danyang Desa) atau dirumah Kepala Desa. Namun sering juga dilakukan di sekolah, masjid, dan sebagainya. ${ }^{6}$ Tujuan utama dari proses hierophanie bersih desa tidak sekedar formalitas ritual tahunan. Tradisi ini memiliki bobot spiritual luar biasa. Paling tidak, melalui ritual tersebut bersih desa menjadi sebuah wahana antara lain, (1) menyatakan syukur kepada Tuhan Yang Maha Kuasa atas ketentraman penduduk dan desa, hasil panenya yang memuaskan, (2) memberi penghormatan kepada para leluhur dan cikal bakal desa yang telah berjasa merintis pembukaan desa setempat, (3) mengharapkan pengayoman (nyuwun wilujeng) dari Tuhan Yang Maha Esa dan Rasulullah, agar panen mendatang lebih meningkat dan hidup masyarakat desa lebih sejahtera. $^{7}$

Terdapat dua hal yang kontras yakni meminta berkah kepada Tuhan serta menghormati leluhur atau orang yang pernah membuka desa (babat desa) yang disebut Danyang. Terkadang ada sebagian masyarakat yang bahkan meminta kepada

${ }_{5}^{5}$ Mulyana, ibid.

6 M. Syahbudin Latief, Persaingan Calon Kepala Desa di Jawa, (Yogyakarta: Media Presindo, 2000), hlm. 107.

${ }_{7}^{7}$ Mulyana, op, cit., hlm. 40. 
Danyang tersebut. Danyang dianggap memiliki kekuatan yang dapat mengabulkan atau mengijabah suatu permohonan.

Masyarakat Desa Banjadowo juga melakukan Upacara Nyadran seperti diatas. Selain bersukur kepada Tuhan, juga dilakukan untuk menghormati leluhur desa yang bernama (Mbah Danyang) Sarwiti. Upacara Nyadran tersebut dilakukan di Cungkup Danyang Sarwiti (Ngasgunting) yang berada di sisi paling barat sebelah selatan dari Kantor Balai Desa Banjardowo. Selain itu ada beberapa orang dari dalam dan luar desa yang sengaja tidur malam disana atau melakukan ritual tertentu untuk mendapatkan wangsit untuk berbagai keperluan, salah satunya togel. Disana dapat pula dijumpai dupa-dupa kecil bekas digunakan si pencari wangsit tersebut. 8

Hal ini menujukan adanya suatu kepercayaan masyarakat tentang kekuatan yang dimiliki Danyang tersebut. Kekuatan itu digunakan untuk keperluan masing-masing. Kepercayaan masyarakat tidak hanya mengenai bantuan yang akan diberikan Danyang Sarwiti ketika mereka berdoa disana. Ada suatu kultus tentang pribadi Danyang Sarwiti yang dipercayai akan berdampak pada komunitas ini. Salah satunya adalah status janda Danyang Sarwiti.

Danyang Desa Banjardowo ini dipercaya menjanda sampai akhir hidupnya.

8 Berdasarkan pengamatan pribadi. Penulis bertempat tinggal dekat dengan Cungkup Ngasgunting tersebut.
Suatu bentuk ikatan antara masyarakat Desa Banajrdowo dengan Danyang Sarwiti adalah ketika ada salah seorang perumpuan yang menjadi janda maka akan dihubungkan nasip ini dengan ke-janda-an Danyang Sarwiti. Begitu pula rentang waktu janda yang akan disandang perempuan tersebut adalah sama seperti Danyang Sarwiti. Begitu kental kepercayaan ini tidak terlepas dari jumlah janda yang ada di Desa Banjardowo. Mungkin cocok untuk menyebut desa ini sebagai Kampung Janda.

\section{Metode Penelitian}

Penelitian ini dilaksanakan di Desa Banjardowo, Kecamatan Lengkong, Kabupaten Nganjuk, Jawa Timur. Terkait dengan permasalahan penelitian, maka desain penelitian yang digunakan adalah metode penelitian Kualitatif-Studi Kasus. Objek penelitian ini adalah masyarakat Desa Banjardowo. Tenik pengumpulan data dilakukan dengan wawancara, observasi dan dokumentasi.

\section{Hasil dan Pembahasan}

\section{Kondisi Geografi}

Desa Banjardowo merupakan bagian dari 14 desa di Kecamatan Lengkong yang masuk wilayah administrasi Kabupaten Nganjuk, Propinsi Jawa Timur. Desa Banjardowo, berbatasan dengan Ds. Jatipunggur, Kec. Lengkong disebelah utara, Ds. Bukur, Kec. Patianrowo disebelah selatan, Ds. Lengkong, Kec. Lengkong 
disebelah timur, dan Ds. Ja'an, Kec. Gondang di sebelah barat. Jarak Desa ini dengan pusat kota Kabupaten Nganjuk adalah $26 \mathrm{~km}$.

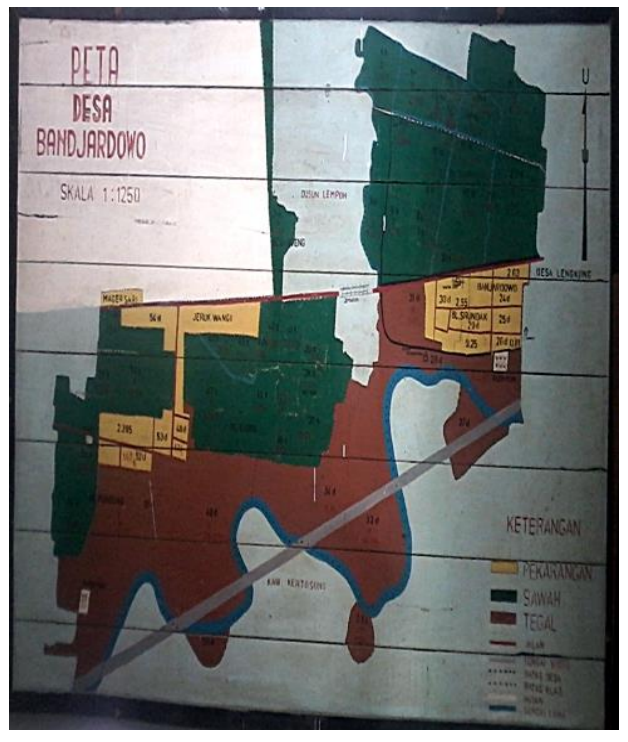

Foto 1. Peta Desa Banjardowo. ${ }^{9}$

Desa Banjardowo terletak pada kordinat longitude 12053058 E longitude $7.5409762 \circ \mathrm{N}$. Luas desa yang mencapai 639,755 Ha terbagi menjadi 146,000 Ha luas sawah, 94,335 Ha luas ladang, 30,525 $\mathrm{Ha}$ luas pemukiman dan $368,895 \mathrm{Ha}$ merupakan luas lahan lainnya di Desa Banjardowo. ${ }^{10}$

\section{Demografi}

Pada tahun 2014, jumlah penduduk Desa Banjardowo sebanyak 2.772 jiwa. Pada tahun 2015 jumlah penduduk mencapai 2.328 jiwa. Sedangkan di tahun 2016 jumlah penduduk Desa Banjardowo

9 Peta Desa Banjardowo, yang terdapat pada ruang kantor Kepala Desa (Sukamto) tahun 2015.

10 Data Desa Banjardowo Tahun 2016. sebanyak 2819 jiwa. Data ini diperinci lewat tabel beikut:

\begin{tabular}{|c|c|c|}
\hline Jumlah Penduduk & Laki-laki & Perempuan \\
\hline Tahun 2014 & 1379 & 1393 \\
\hline Tahun 2015 & 1178 & 1150 \\
\hline Tahun 2016 & 1412 & 1407 \\
\hline
\end{tabular}

Tabel 1. Jumlah Penduduk Banjardowo 20142016. ${ }^{11}$

Jumlah penduduk yang mencapai 2819 jiwa di tahun 2016 mayoritas dari mereka adalah beragama Islam yakni sebesar 1300 jiwa beragama Islam dan 18 beragama Kristen. ${ }^{12}$ Mengenai pekerjaan masyarakat Desa Banjardowo, penduduk laki-laki produktif kebanyakan bekerja sebagai tenaga pabrik dan bangunan di luar desa seperti di Surabaya, Sidoarjo, luar pulau seperti di Kalimantan, Sumatera bahkan hingga Malaysia. Secara rinci profesi masyarakat Banjardowo dapat dilihat dalam tabel berikut

\begin{tabular}{|c|l|c|c|}
\hline No. & \multicolumn{1}{|c|}{$\begin{array}{c}\text { Jenis } \\
\text { Pekerjaan }\end{array}$} & $\begin{array}{c}\text { Laki- } \\
\text { laki } \\
\text { (Orang) }\end{array}$ & $\begin{array}{c}\text { Permpuan } \\
\text { (Orang) }\end{array}$ \\
\hline 1. & Petani & 192 & 100 \\
\hline 2. & Buruh Tani & 67 & 43 \\
\hline 3. & $\begin{array}{l}\text { Buruh Migran } \\
\text { Perempuan }\end{array}$ & 12 & - \\
\hline 4. & $\begin{array}{l}\text { Buruh Migran } \\
\text { Laki-laki }\end{array}$ & - & 10 \\
\hline 5. & $\begin{array}{l}\text { Pegawai } \\
\text { Negeri Sipil }\end{array}$ & 12 & 14 \\
\hline 6. & $\begin{array}{l}\text { Pengerajin } \\
\text { Industri } \\
\text { Rumah } \\
\text { Tangga }\end{array}$ & 1 & - \\
\hline 7. & $\begin{array}{l}\text { Pedagang } \\
\text { Keliling }\end{array}$ & 11 & 22 \\
\hline 8. & Peternak & 152 & 211 \\
\hline 9. & Dokter Swasta & - & - \\
\hline 10. & Bidan Swasta & - & 2 \\
\hline
\end{tabular}

11 Data Desa Banjardowo Tahun 2015 dan 2016.

12 Data Desa Banjardowo Tahun 2016. 


\begin{tabular}{|l|l|l|l|}
\hline 11. & Pensiunan & 22 & \\
\hline
\end{tabular}

Tabel 2. Mata Pencarian Penduduk. ${ }^{13}$

Data di atas masih ditambah golongan masyarakat yang tidak bekerja (pengangguran) sebanyak 109 jiwa. Mengenai tingkat pendidikan masyarakat Desa Banjardowo terbilang tinggi, yakni mayoritas sudah lulus SMA. Pendidikan memegang peranan penting dalam pola pikir penduduk Banjardowo. Data yang diperoleh dari Kantor Kepala Desa Banjardowo tentang pendidikan masyarakat Banjardowo tahun 2016 sebagai berikut:

\begin{tabular}{|c|c|c|c|}
\hline No & $\begin{array}{l}\text { Tingkat } \\
\text { Pendidikan }\end{array}$ & $\begin{array}{l}\text { Laki- } \\
\text { laki }\end{array}$ & Perempuan \\
\hline 1. & $\begin{array}{l}\text { Usia } \quad 3-6 \\
\text { tahun belum } \\
\text { masuk TK }\end{array}$ & 41 & 11 \\
\hline 2. & $\begin{array}{l}\text { Usia } \quad 7-6 \\
\text { tahun sedang } \\
\text { TK }\end{array}$ & 36 & 42 \\
\hline 3. & $\begin{array}{lr}\text { Usia } & 7-18 \\
\text { tahun } & \text { tidak } \\
\text { pernah } & \\
\text { sekolah } & \\
\end{array}$ & 20 & 37 \\
\hline 4. & $\begin{array}{l}\text { Usia 7-18 } \\
\text { tahun sedang } \\
\text { sekolah }\end{array}$ & 204 & 208 \\
\hline 5. & $\begin{array}{lr}\text { Usia } & 18-56 \\
\text { tahun } & \text { tidak } \\
\text { pernah } & \\
\text { sekolah } & \end{array}$ & 12 & 14 \\
\hline 6. & $\begin{array}{lr}\text { Usia } & 18-56 \\
\text { tahun } & \text { tidak } \\
\text { tamat SD }\end{array}$ & 200 & 225 \\
\hline 7. & $\begin{array}{lr}\text { Usia } & 18-56 \\
\text { tahun } & \text { tidak } \\
\text { tamat SLTP }\end{array}$ & 1 & - \\
\hline 8. & $\begin{array}{lr}\text { Usia } & 18-56 \\
\text { tahun } & \text { tidak } \\
\text { tamat SLTA }\end{array}$ & 392 & 325 \\
\hline 9. & $\begin{array}{l}\text { Tamat SD/ } \\
\text { Sederajat }\end{array}$ & 432 & 437 \\
\hline 10. & $\begin{array}{l}\text { Tamat SMPI } \\
\text { Sederajat }\end{array}$ & 270 & 269 \\
\hline 11. & Tamat SMA & 254 & 256 \\
\hline
\end{tabular}

${ }^{13}$ Data Desa Banjardowo Tahun 2016.

\begin{tabular}{|c|l|c|c|}
\hline & Sederajat & & \\
\hline 12. & $\begin{array}{l}\text { Tamat D-1/ } \\
\text { Sederajat }\end{array}$ & 1 & 3 \\
\hline 13. & $\begin{array}{l}\text { Tamat D-2/ } \\
\text { Sederajat }\end{array}$ & - & - \\
\hline 14. & $\begin{array}{l}\text { Tamat D-3/ } \\
\text { Sederajat }\end{array}$ & 1 & 1 \\
\hline 15. & $\begin{array}{l}\text { Tamat S-1/ } \\
\text { Sederajat }\end{array}$ & 17 & 13 \\
\hline 16. & $\begin{array}{l}\text { Tamat S-2/ } \\
\text { Sederajat }\end{array}$ & - & - \\
\hline 17. & $\begin{array}{l}\text { Tamat S-3/ } \\
\text { Sederajat }\end{array}$ & - & - \\
\hline
\end{tabular}

Tabel 3. Pedidikan Penduduk. ${ }^{14}$

Menurut Sejarahnya, nama desa ini diambil dari komunitas keluarga sedarah yang rumahnya saling berjajar (atau Berbanjar, Jawa: Banjar/ mBanjar) dan sangat panjang (Jawa: Dowo) deretannya, maka dari itu disebut Desa Banjardowo. ${ }^{15}$ Pendapat lain, bahwa desa ini bernama Banjardowo karena pada masa awal adanya pemukiman penduduk disini, ketika para penduduk yang notabene petani, sering menanam benih padi secara berjajar (mBanjar) dan cara menanamnya memanjang (dowo) darisanalah disebut Banjardowo. ${ }^{16}$ Mengenai tahun berdiri, dalam data Desa Banjardowo tahun 2016 disebutkan Desa Banjardowo berdiri pada tahun 1938. Namun, sebenarnya tidak diketahui kapan pastinya Desa Banjardowo ini berdiri. Perlu pengkajian lebih lanjut untuk menentukan angka tahun yang tepat dalam pendirian Desa Banjardowo.

\footnotetext{
${ }^{14}$ Data Desa Banjardowo Tahun 2016.

15 Cerita tersebut adalah hipotesis pertama tentang pemberian nama Desa Banjardowo.

16 Transliterasi hasil wawancara dengan Kasmadi (66 tahun), yang sejak dulu leluhurnya sudah tinggal di Desa Banjardowo.
} 
Persepsi Masyarakat Desa Banjardowo

Terhadap (Mitos) Status Janda

Kata mitos yang dalam bahasa

Inggris myth berasal dari bahasa Latin

mythus atau dari bahasa Yunani kuno

mythos atau muthos yang bermakna cerita

atau fabel (dongeng). ${ }^{17}$ Mitos dalam konteks

mitologi-mitologi lama mempunyai

pengertian suatu bentukan dari masyarakat

yang berorientasi dari masa lalu atau dari bentukan sejarah yang bersifat statis dan kekal. ${ }^{18}$ Atau menurut J. van Baal, mitos didefinisikan sebagai cerita didalam kerangka sistem sesuatu religi yang dimasa lalu atau dimasa kini telah atau sedang berlaku sebagai kebenaran keagamaan. ${ }^{19}$ Mitos merupakan serangkaian cerita imajiner yang berhubungan dengan alam, dewa-dewi, atau manusia yang dipercayai dan menjadi tradisi.

Mitos status janda seumur hidup menjadi suatu hal yang dipercayai di Desa Banjardowo. Masyarakatnya meyakini, apa yang sudah dipercayaai secara turuntemurun ini. Kepercayaan terhadap mitos

17 Ayatullah Humaeni, "Makna Kultural Mitos dalam Budaya Masyarakat Banten", Antropologi Indonesia, Vol. 33, No. 3, September-Desember 2012, hlm. 165.

18 Sri Iswidayati, "Fungsi Mitos Dalam Kehidupan Sosial Budaya Masyarakat Pendukungnya", Harmonia, Vol. 8, No. 2, MeiAgustus 2007, hlm. 180.

19 Definisi ini memberi ruang untuk tetap mengakui sebuah cerita sebagai mitos yang sekarang sudah tidak lagi diterima sebagai kebenaran keagamaan, tetapi jauh dimasa lalu tetap berperan sebagai kebenaran keagamaan. Lihat J. van Baal, Sejarah dan Pertumbuhan: Teori Antropologi Budaya (Hingga Dekade 1970) Jilid 1, (Jakarta: Gramedia, 1987), hlm. 44. status janda seumur hidup di Desa Banjardowo berawal dari kisah Danyang Desa Banajrdowo sendiri. Danyang adalah sebutan untuk orang yang sudah membabat alas atau orang pertama yang pertama kali mendirikan desa. ${ }^{20}$ Danyang Desa Banjardowo bernama Sarwiti21, yang diceritakan selalu berpakian lurik-lurik. ${ }^{22} \mathrm{Di}$ Desa Banjardowo terdapat tempat pemujaan untuk Sarwiti yang disebut Ngasgunting ${ }^{23}$

20 Sebutan ini digunakan umumnya oleh masyarakat di wilayah Jawa Timur dan Tengah. Menurut Sukardi, dahyang atau danyang adalah cikal bakal penditi suatu desa yang dikeramatkan oleh keturunannya. Baca Tanto Sukardi, Tanam Paksa di Banyumas: Kajian mengenai Sistem, Pelaksanaan, dan Dampak Sosial Ekonomi, (Yogyakarta: Pustaka Pelajar, 2014), hlm. 180.

21 Nama ini, di ceritakan turun-temurun kepada orang-orang Banjardowo. Salah satunya kepada Kasmadi yang pada masa mudanya berprofesi sebagai Bopo dalam kesenian Jaranan. Kesenian ini dalam permainanya selalu meminta ijin kepada para arwah leluhur setempat dan pada kesempatan tersebut, Kasmadi selalu meminta restu kepada Danyang Sarwiti.

22 Transliterasi hasil wawancara dengan Minah dan Nyami (54 Tahun) bahwa Danyang Sarwiti memiliki kebiasaan berpakaian lurik-lurik berwarna coklat dengan terusan jarik yang juga lurik-lurik. Sritunut (61 Tahun) menambahkan, masyarakat Banjardowo dilarang memakai pakaian yang sama dengan Mbah Danyang Sarwiti, jika pantangan dilanggar dapat berujung musibah bahkan sampai dengan kematian.

23 Oleh masyarakat sekitar diartikan sebagai cungkup, padahal istilah cungkup dipakai sebagai bangunan yang melindungi makam dan Ngasgunting bukan makam. "Paijah", seorang janda, mendiskreditkan pendapat umum, bahwa tempat tinggal gaib dari Danyang Sarwiti bukan di tempat yang sekarang disebut Ngasgunting, tetapi di selatan tangkis (tangkis adalah gundakan tanah penahan banjir dekat sungai ). Paijah juga mengatakan, disekitar selatan tangkis dulu ada gong dan peralatan sinden jawa lain yang terbuat dari emas dan ketika malam tertentu lantunan musik akan terdengar dari tempat 
nama ini memiliki makna - Pohon Ingas, yang posisinya menyilang atau menggunting (Ngasgunting). Pohon tersebut hidup di dekat Cungkup, sehingga masyarakat Desa Banjardowo menyebutnya Ngasgunting. ${ }^{24}$ Sekarang pohon tersebut sudah tidak ada, namun Cungkup ini masih tetap disebut Ngasgunting.

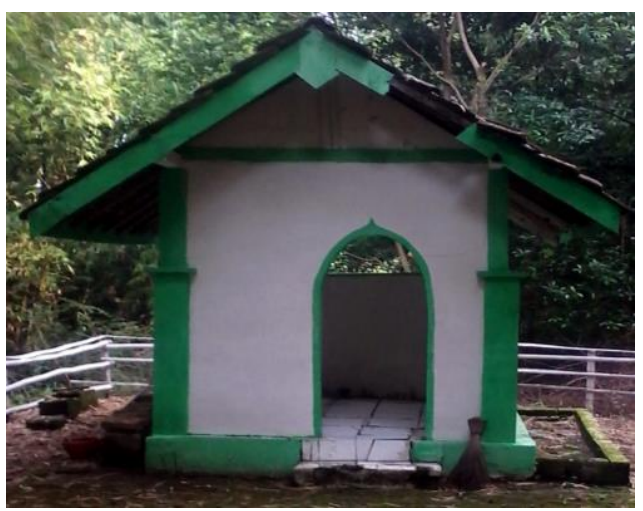

Foto 2. Ngasgunting (Cungkup)

Sarwiti adalah leluhur desa yang sampai akhir hidupnya berstatus Janda. Terdapat kepercayaan pada masyarakat Banjardowo bahwa ketika ada seorang wanita yang janda, maka wanita tersebut akan menjanda seumur hidupnya. Dia (Si

tersebut bahkan sampai sekarang, Paijah juga percaya bahwa Danyang Sarwiti sampai sekarang masih hidup dan tidakakan pernah mati. Di Ngasgunting juga ada batu bata besar, semacam batu-bata terakota untuk pembangunan candi. Terlepas dari itu, hasil transliterasi wawancara dengan Nyami (54 Tahun) menyebutkan bahwa upacara Nyadranan (bersih desa) diawali dengan pergi ke Ngasgunting sambil membawa makanan untuk diberkahi setelah itu makanan boleh dibawa pulang kembali. Nyadranan di Desa Banjardowo dilakukan pada saat panen padi sekitar bulan April/ Mei di hari Senin Pon.

${ }^{24}$ Pernyataan ini juga didapatkan dari Kasmadi (66 Tahun), yang jarak rumahnya sekitar 200 meter dari Ngasgunting.
Janda) tidak akan bisa menikah lagi. ${ }^{25} \mathrm{Hal}$ ini dikaitkan dengan status Danyang Banjardowo yang janda. Kisah ini sangat dipercayai oleh masyarakat Banjardowo sebagai semacam takdir yang diberikan dari leluhur desa kepada anak-cucu keturunannya sampai kapanpun. Seolaholah menjadi nyata, saat fakta menunjukan jumlah Janda di kawasan ini sangat banyak, yaitu mencapai 157 jiwa tahun 2014 dan 217 jiwa tahun 2015 dan 238 jiwa ditahun 2016. Hasil ini dapat dilihat pula dari jumlah KK Perempuan antara tahun 2014 hingga $2016 .{ }^{26}$

Terlepas dari banyaknya janda, para janda ini memilih menjada dan tidak menikah lagi, padahal dimungkinkan diusianya menjanda untuk dapat membangun rumah tangga yang baru. Sebut saja A, dia berusia sekitar 25 tahun dan sudah menjanda dari tahun \pm 2013 , dia miliki dua orang anak, padahal sangat dimungkinkan sekali untuk segera dia menikah, tapi ternyata dia tetap menjanda. Seorang PNS bernama W yang menjanda tahun 2004, pada saat usianya 49 tahun, bahkan sampai sekarang (saat dia sudah pensiun) belum ada tanda-tanda untuk menikah.

Begitu banyak cerita semacam ini hingga jumlah ceritanya puluhan, namun, kasus yang dihadapi sama - menjanda dan

25 Hasil transliterasi wawancara dengan Sritunut (61 Tahun), yang juga seorang janda di Desa Banjardowo. dan 2016.
26 Data Desa Banjardowo Tahun 2015 
tidak menikah lagi. Fakta unik lain yang terungkap, bahwa banyak wanita yang menjanda bahkan sampai akhir hidupnya, semisal alm. X (meninggal tahun 2015), Mbah $Y$ (alm), dan lain-lain. Di Desa Banjardowo, orang yang menjadi janda kebanyakan karena suaminya meninggal. Namun, angka perceraian juga tinggi di sini. Kebanyakan orang Banjardowo memiliki suami dari luar desa, jadi tidak aneh jika di Banjardowo banyak janda tapi jarang ada yang duda.

Kasus tentang kepercayaan terhadap mitos bisa kita analisa dengan kritis. Kepercayaan merupakan salah satu unsur dari kebudayaan, seperti yang dikatakan E. B. Tylor bahwa kebudayaan adalah kompleks yang mencakup pengetahuan, kepercayaan, kesenian, moral, hukum, adat istiadat dan lain kemampuankemampuan serta kebiasaan-kebiasaan yang didapatkan oleh manusia sebagai anggota masyarakat. ${ }^{27}$ Sedangkan Selo Soemardjan dan Soelaeman Soemardi memandang kebudayaan sebagai semua hasil karya, rasa, dan cipta Masyarakat. ${ }^{28}$ Lewat pendapat tersebut dapat disimpukan bahwa kepercayaan diciptakan dari, untuk, dan oleh manusia itu sendiri. Kepercayaan tersebut adalah jawaban dari pertanyaan yang tidak dapat dijawab oleh logika manusia (atau masyarakat).

27 Soerjono Soekanto dan Budi Sulistyowati, Sosiologi: Suatu Pengantar, (Jakarta: Raja grafindo, 2012), hlm. 150. 28 Ibid., hlm 151.
Kalau boleh menafikan, kiranya status janda seumur hidup ini masih dipercayai namun, ada seorang perempuan desa yang bernama $T$ yang dulu bersuamikan $R$ (Pria dari luar desa) kemudian memiliki anak bernama $A$, setelah itu mereka bercerai, dan A yang penduduk asli Desa Banjardowo ternyata berhasil menikah kembali (tahun 2014) dengan orang lain bernama $\mathrm{W}$. Kisah $\mathrm{T}$ ini seolah-olah berusaha mematahkan mitos yang dipercayai selama ini tentang status janda seumur hidup. Serupa dengan A, seorang janda bernama $S$ juga dapat menikah lagi. Anehnya, informan masih saja mempercayai mitos status janda seumur hidup tersebut. Mereka menyangkal apa yang terjadi pada $\mathrm{A}$ atau S. Kalau boleh menginterpretasikan, mereka menganggap kejadian ini 1 banding 1000 yang jarang sekali terjadi dan tidak dapat mengoyahkan mitos tersebut ataupun mereka menganggap peristiwa janda yang dapat menikah lagi tersebut sudah takdir dari tuhan (Allah). ${ }^{29}$

Masyarakat Desa Banjardowo masih mempertahankan kearifan lokalnya. Tentu, kearifan lokal ini berdampingan dengan agama yang juga dianut oleh masyarakat Banjardowo. Kearifan lokal terkadang merupakan antithesa dari ajaran agama (Islam $\left.{ }^{30}\right)$. Penelitian Clifford Geertz ${ }^{31}$

29 Hasil pengamatan pribadi dan wawancara dengan beberapa saksi yang tidak disebutkan. Banjardowo.
30 Agama mayoritas masyarakat desa 
dalam Robertson yang menyebutkan, pada masa sekarang ini sistem keagamaan di pedesaan Jawa pada umumnya terdiri dari suatu perpaduan yang seimbang dari unsurunsur Animisme, Hindu, dan Islam, suatu sinkretisme dasar yang merupakan tradisi rakyat yang sesungguhnya, suatu substratum dasar dari peradabannya. ${ }^{32}$

Mayoritas masyarakat Banjardowo (secara tidak sadar) beraliran vitalisme. Vitalisme merupakan salah satu aliran dalam filsafat yang menyatakan adanya kekuatan di ular alam. Kekuatan tersebut memiliki peranan yang esensial mengatur segala sesuatu yang terjadi di alam semesta ini. Menurut aliran ini, rasio hanyalah alat yang

31 Pada hal ini pula Cliford Geertz, membagi masyarakat Jawa menjadi tiga kelompok: kaum santri abangan dan priyayi. Menurutnya kaum santri adalah penganut agama Islam yang taat, kaum abangan adalah penganut Islam secara nominal atau penganut Kejawen, sedangkan kaum priyayi adalah kaum bangsawan. Baca Suwardi Endraswara, Etnologi Jawa: Penelitian, perbandingan, dan Pemaknaan Budaya, (Yogyakarta: CAPS, 2015), hlm. 85.

32 Sebelum kedatangan agama Hindhu sekitar tahun $400 \mathrm{SM}$, tradisi keagamaan dari berbagai suku Melayu masih mengandung unsur-unsur animisme. Setelah berabad-abad kemudian tradisi animisme di Jawa ini terbukti mampu menyerap ke dalam unsur-unsur yang berasal dari Hindhu dan Islam yang datang belakangan pada abad XV Masehi. Artikel Marzuki, Tradisi Dan Budaya Masyarakat Jawa Dalam Perspektif Islam. (online). Tersedia: http://eprints.uny.ac.id/id/eprint/2609 diunduh 12 Mei 2016.

pada 16 April 2016. Hal ini senada dengan yang siampaikan oleh Suwardi Endraswara bahwa masyarakat jawa terkenal dengan sifat singkritisme kepercayaanya. Semua budaya luar diserap dan ditafsirkan menurut nilainilai Jawa sehingga kepercayaan seseorang kadangkala menjadi kabur. Lihat Endraswara, op, cit., hlm. 85. berfungsi untuk merasionalisasikan hal-hal atau keputusan-keputusan yang sebetulnya tidak sulit dipahami. Seperti sudah adanya fakta tentang terpatahkannya mitos janda seumur hidup, namun mereka tetap mempercayaai eksistensi kekuatan Danyang Sarwti.

Modernisasi yang sedang buming di indonesia, merubah sikap sebagian masyarakat Indonesia untuk melihat tradisi dengan perspektif masa kini. Efek modernisasi juga sampai di desa Banjardowo. Beberapa orang (minoritas) di desa Banjardowo sudah "berdamai dengan mitos". Mereka menjadi kurang meyakini mitos janda seumur hidup. Hal ini juga disebabkan, karena ada beberapa janda yang berhasil menikah lagi. Juga karena pendidikan yang semakin tinggi di desa ini, membuat segala sesuatu yang tidak wajar bisa dikritisi dengan baik.

Mengkaji permasalahan ini, mitos status janda seumur hidup memang masih menjadi kepercayaan masyarakat Desa Banjardowo. Kekuatan apapun tidak bisa melarang ataupun menolak perspektif tersebut karena ini merupakan kebudayaan asli Indonesia yang menjadi ciri khas bangsa Indonesia. Menurut George J. Mouly perkembangan ilmu pengetahuan berawal dari animisme. ${ }^{33}$ Sedangkan Auguste Comte yang membagi tingkatan perkembangan pengetahuan yaitu, religius, metafisik dan

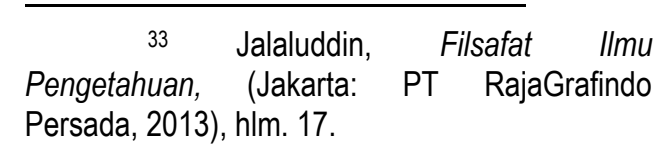


positif. Dalam tahap pertama maka asas religilah yang dijadikan postulat ilmiah sehingga ilmu merupakan deduksi atau penjabatan dari ajaran religi. ${ }^{34}$ Dari pendapat dua tokoh tersebut dapat di artikan bahwa zaman religius (atau oleh Mouly disebut animisme) adalah masa awal pengenalan manusia terhadap ilmu pengetahuan. Sedangkan sekarang adalah tahun 2017, sudah waktunya zaman positif (menurut Comte) dilaksanakan, suatu zaman dimana asas-asas yang dipergunakan diuji secara positif dalam proses verifikasi yang objektif. 35

\section{Kesimpulan}

Desa Banjardowo, dengan luas wilayah $639.755 \mathrm{Ha}$, memiliki jumlah penduduk 2.328 jiwa. Sedangkan jumlah janda di desa ini adalah 217. Angka janda yang sangat tinggi untuk ukuran sebuah desa. Jumlah janda yang sedemikian banyak, memunculkan kepercayaan yang sudah dianut sejak dulu bahwa orang yang menjadi janda, akan menjanda seumur hidupnya, hal ini dikaitkan dengan status janda yang dimiliki oleh Danyang Sarwiti. Menurut orang banjar jumlah janda yang banyak ini akibat Danyangnya yang juga janda. Kepercayaan ini sudah berlangsung sangat lama dan masih dipercayaai sampai sekarang. Ketika berfilsafat, pertanyaan manusia yang tidak dapat dijawab oleh

34 Jujun S. Suryasumantri, Filsafat IImu: Sebuah Pengantar Populoer, (Jakarta: Pustaka Sinar Harapan,1990), hlm. 25. 35 Ibid.. logika pasti akan dihubungkan dengan yang gaib.

Begitu juga dengan kasus mitos di Desa Banjardowo ini. Seolah ingin mematahkan mitos ada kejadian langka, seorang wanita janda tetapi dapat menikah lagi. Suatu hal yang bertentangan dengan mitos yang ada. Masyarakat Banajardowo pada umumnya beragama Islam namun, masih mempertahankan tradisi menghormati leluhur (Danyang Sarwiti) bahkan masih mempercayai mitos yang berkaitan dengannya. Padahal ada hal yang sangat kontradiktif antara ajaran Islam dengan animisme atau meminta selain kepada tuhan.

Dilihat dari sudut pandang politik memori, mitos semacam ini sangat lumrah terjadi bahkan tiap wilayah mempunyai nilai unik tersendiri dalam merangkai mitosnya. Dalam catatan lain memori dan mitos sering berseberangan dengan apa yang disebut sebagai sejarah yang berpikir positifis (no dokumen no histori), oleh karenanya merekam masa lalu dengan mitos adalah cara yang terbaik manakala data itu tidak ditemukan. Hal ini perlu diketengahkan untuk bias menarik sejarah dalam narasi masa lalu lewat sastra seperti yang diketengahkan Jan Vansina. Mitospu sedemikian, upaya menarik dan sekaligus meladangkan memori masa lalu dengan karya sejarah perlu diketengahkan lewat pengumpulan data yang terekam dalam benak masyarakatnya. 


\section{Daftar Pustaka}

Baal, J. van. 1987. Sejarah dan Pertumbuhan: Teori Antropologi Budaya (Hingga Dekade 1970) (Volume 1). Jakarta: Gramedia.

Data Desa Banjardowo tahun 2015.

Data Desa Banjardowo tahun 2016.

Endraswara, Suwardi. 2015. Etnologi Jawa:

Penelitian, perbandingan, dan Pemaknaan Budaya. Yogyakarta: CAPS.

Humaeni, Ayatullah. 2012. Makna Kultural Mitos dalam Budaya Masyarakat Banten. Jurnal: Antropologi Indonesia. 33(3).

Iswidayati, Sri. 2007. Fungsi Mitos Dalam Kehidupan Sosial Budaya Masyarakat Pendukungnya, Harmonia: Jurnal Pengetahuan dan Pemikiran Seni. 8(2).

Jalaluddin. 2013. Filsafat IImu Pengetahuan. Jakarta: Raja Grafindo Persada.

Latief, M. Syahbudin. 2000. Persaingan Calon Kepala Desa di Jawa. Yogyakarta: Media Presindo.

Marzuki, Tradisi Dan Budaya Masyarakat Jawa Dalam Perspektif Islam. (online). Tersedia:

http://eprints.uny.ac.id/id/eprint/260 g diunduh 12 Mei 2016.

Mulyana. 2006. Spiritualisme Jawa: Meraba

Demensi dan Pergulatan Religiusitas Orang Jawa, Jurnal Kebudayaan Jawa, 1(2).
Soekanto, Soerjono dan Budi Sulistyowati. 2012. Sosiologi: Suatu Pengantar. Jakarta: Rajagrafindo.

Sukardi, Tanto. 2014. Tanam Paksa di Banyumas: Kajian mengenai Sistem, Pelaksanaan, dan Dampak Sosial Ekonomi. Yogyakarta: Pustaka Pelajar.

Suryasumantri, Jujun S. 1990. Filsafat IImu: Sebuah Pengantar Populoer, Pustaka Sinar Harapan: Jakarta. 
Responden

\begin{tabular}{|c|c|c|c|c|}
\hline Nama & Usia & $\begin{array}{c}\text { Status } \\
\text { Perkawinan }\end{array}$ & Pekerjaan & Alamat \\
\hline Kasmadi & 62 th & Menikah & Petani & \multirow{8}{*}{$\begin{array}{c}\text { Desa } \\
\text { Banjardowo }\end{array}$} \\
\hline Painem & 73 th & Janda & Pedagang & \\
\hline Paijah & 75 th & Janda & Pedagang & \\
\hline Paimah & 64 th & Janda & Pedagang & \\
\hline Sritunut & 63 th & Janda & Ibu Rumah tangga & \\
\hline Nyami & 58 th & Menikah & Pedagang & \\
\hline Minah & 52 th & Janda & Petani & \\
\hline Wiwik & 63 th & Janda & Pensiunan & \\
\hline
\end{tabular}

